\title{
Evidence for Altered Glutamine Metabolism in Human Immunodeficiency Virus Type 1 Infected Primary Human CD4 ${ }^{+} \mathrm{T}$ Cells
}

\author{
Andrea Hegedus,' Maia Kavanagh Williamson,, Mariam B. Khan,, Julianna Dias Zeidler? \\ Andrea T. Da Poian, Tatiana El-Bacha, Eduard A. Struys, and Hendrik Huthoff ${ }^{1, *}$
}

\begin{abstract}
Glutamine is a conditionally essential amino acid that is an important metabolic resource for proliferating tissues by acting as a proteinogenic amino acid, a nitrogen donor for biosynthetic reactions and as a substrate for the citric acid or tricarboxylic acid cycle. The human immunodeficiency virus type 1 (HIV-1) productively infects activated $\mathrm{CD} 4^{+} \mathrm{T}$ cells that are known to require glutamine for proliferation and for carrying out effector functions. As a virus, HIV-1 is furthermore entirely dependent on host metabolism to support its replication. In this study, we compared HIV-1 infected with uninfected activated primary human CD4 ${ }^{+} \mathrm{T}$ cells with regard to glutamine metabolism. We report that glutamine concentrations are elevated in HIV-1-infected cells and that glutamine is important to support HIV-1 replication, although the latter is closely linked to the glutamine dependency of cell survival. Metabolic tracer experiments showed that entry of glutamine-derived carbon into the citric acid cycle is unaffected by HIV-1 infection, but that there is an increase in the secretion of glutaminederived glutamic acid from HIV-1-infected cells. Western blotting of key enzymes that metabolize glutamine revealed marked differences in the expression of glutaminase isoforms, KGA and CAG, as well as the PPAT enzyme that targets glutamine-derived nitrogen toward nucleotide synthesis. Altogether, this demonstrates that infection of $\mathrm{CD}^{+} \mathrm{T}$ cells with HIV-1 leads to considerable changes in the cellular glutamine metabolism.
\end{abstract}

Keywords: HIV-1, CD4 ${ }^{+} \mathrm{T}$ cells, glutamine, glutamic acid, metabolism, glutaminase

\section{Introduction}

$\mathbf{L}$ IKE ALL VIRUSES, human immunodeficiency virus type 1 (HIV-1) is entirely dependent on host cells to provide the metabolic resources to support its replication. While HIV-1 is able to infect several types of immune cells, its productive and lytic replication occurs predominantly in activated $\mathrm{CD} 4^{+} \mathrm{T}$ cells, but resting $\mathrm{CD}^{+} \mathrm{T}$ cells are refractory to HIV replication. The transition from resting to activated $\mathrm{CD} 4^{+} \mathrm{T}$ cells is known to coincide with a metabolic switch that is characterized by the upregulation of glycolysis and glutaminolysis in activated cells. ${ }^{1,2}$ The field of immunometabolism has recently attracted increasing interest with regard to understanding how metabolic processes support immunological effector functions and the potential therapeutic exploitation thereof., ${ }^{3,4}$
Likewise, understanding the metabolic requirements of viral infections holds the promise of identifying new antiviral strategies. ${ }^{5}$ Viral dependency on and modulation of cellular metabolism has now been demonstrated for a diverse set of viruses, including human cytomegalovirus (HCMV), herpes simplex virus type 1 (HSV-1), Influenza, Sindbis, Mayaro, Dengue, and HIV. ${ }^{5-17}$ Currently, the best-documented example is HCMV, which has been shown to depend on fatty acid synthesis to support membrane production for virion assembly. ${ }^{5-7}$ This work has provided proof of principle that fatty acid synthesis can be targeted as an antiviral strategy against HCMV infections. ${ }^{5,18}$ Comparison with the closely related HSV-1 virus furthermore rationalized the differential efficacy of nucleotide inhibitors as inhibitors of the two herpesviruses, with HCMV being less dependent on nucleotide synthesis than HSV-1. ${ }^{12}$

${ }^{1}$ Department of Infectious Diseases, King's College London, London, United Kingdom.

${ }^{2}$ Instituto de Bioquímica Médica Leopoldo de Meis, Universidade Federal do Rio de Janeiro, Rio de Janeiro, Brazil.

${ }^{3}$ Instituto de Nutrição Josué de Castro, Universidade Federal do Rio de Janeiro, Rio de Janeiro, Brazil.

${ }^{4}$ Metabolic Unit, Department of Clinical Chemistry, VU Medical Center, Amsterdam, the Netherlands.

*Current affiliation: Jena School for Microbial Communication, Friedrich Schiller University Jena, Jena, Germany.

(C) Andrea Hegedus et al. 2017; Published by Mary Ann Liebert, Inc. This is an Open Access article distributed under the terms of the Creative Commons Attribution License, which permits unrestricted use, distribution, and reproduction in any medium, provided the original work is properly cited. 
We have previously reported that HIV-1 replication is dependent on the highly glycolytic phenotype of activated $\mathrm{CD} 4^{+}$ T cells and infection of these cells with HIV-1 further elevates their glucose consumption. ${ }^{11}$ This work corroborated an earlier report that glycolytic intermediates are elevated in HIV-1-infected versus -uninfected $\mathrm{CD} 4{ }^{+}$T cells. ${ }^{10}$ In addition to glucose, glutamine is an important metabolic resource for activated $\mathrm{T}$ cells and indeed more generally for proliferating tissues. ${ }^{2} \mathrm{We}$, therefore, set out to determine if glutamine metabolism is in any way affected by the infection of $\mathrm{CD} 4^{+} \mathrm{T}$ cells with HIV-1. There is ample precedence for viral dependency on or manipulation of glutamine metabolism by viruses as diverse as hepatitus $\mathrm{C}$ virus (HCV), ${ }^{19}$ Adenovirus, ${ }^{20}$ infectious spleen and kidney necrosis virus (ISKNV), ${ }^{21}$ Kaposi sarcoma herpes virus (KSHV) ${ }^{22}$ Vaccinia virus, ${ }^{23} \mathrm{HCMV}-1,{ }^{24}$ and Dengue virus. ${ }^{25}$

We report that glutamine metabolism of primary human $\mathrm{CD}^{+} \mathrm{T}$ cells is responsive to HIV-1 infection as evidenced by increased intracellular glutamine concentrations and increased secretion of glutamine-derived glutamic acid. Interestingly, entry of glutamine-derived carbon into the citric acid cycle is unaffected by infection with HIV-1, but the expression of several enzymes that metabolize glutamine into glutamic acid is altered in HIV-1-infected cells.

\section{Materials and Methods}

\section{Cell culture}

Whole blood was obtained from healthy volunteers by venipuncture and peripheral blood mononuclear cells were isolated by density gradient centrifugation using Lymphoprep according to the manufacturer's instructions (AxisShield). $\mathrm{CD}^{+} \mathrm{T}$ lymphocytes were isolated by magnetic sorting using the $\mathrm{CD} 4^{+}$Isolation Kit II (Miltenyi Biotec). Purity of isolated population was assessed by flow cytometry, and was typically $>95 \%$. Human primary lymphocytes were cultured in RPMI-1640 media supplemented with $10 \%$ fetal bovine serum (FBS), 1\% penicillin/streptomycin (P/S), and $15 \mathrm{IU} / \mathrm{ml}$ interleukin 2 (IL-2) following activation with CD3/ CD28 T cell activator Dynabeads (all from Invitrogen).

$\mathrm{CD}^{+} \mathrm{T}$ cell lines, Jurkat and CEM-ss, were maintained in RPMI-1640 with $10 \%$ FBS and 1\% P/S. Human endothelial kidney 293 T (HEK 293T) and TZM-bl cells were maintained in high-glucose Dulbecco's modified Eagle's medium (DMEM; Invitrogen) supplemented with 10\% FBS and 1\% P/S.

Media for glutamine titration and metabolic tracer experiments were made up from DMEM powder (Sigma) lacking glucose, pyruvate, glutamine, sodium bicarbonate, and phenol red; these components were added to obtain standard DMEM formulation with $1 \mathrm{~g} /$ liter glucose, $10 \mathrm{mM}$ pyruvate, $0,0.2,0.5$ and $1 \mathrm{mM}$ final glutamine concentration. Media containing ${ }^{13} \mathrm{C}$-labeled glutamine $\left(\mathrm{Gln}-3-{ }^{13} \mathrm{C}\right)$ and pyruvate $\left(\mathrm{Pyr}-2-{ }^{13} \mathrm{C}\right)$ for enrichment analysis by mass spectrometry were made using DMEM powder as above, with $2 \mathrm{mM}$ glutamine and pyruvate (1 $\mathrm{mM}$ labeled and $1 \mathrm{mM}$ unlabeled compound; all from Sigma). Media with universally labeled U- ${ }^{13} \mathrm{C}$-glutamine (Sigma) for nuclear magnetic resonance (NMR) analyses were prepared as above with $2 \mathrm{mM}$ final $\mathrm{U}-{ }^{13} \mathrm{C}$-glutamine concentration.

All these media were supplemented with $10 \%$ dialyzed FBS (Sigma) and 1\% P/S (Invitrogen), pH adjusted to 7.27.4, and filter sterilized before use. All cell cultures were maintained at $37^{\circ} \mathrm{C}$ with $5 \% \mathrm{CO}_{2}$.

\section{Virus production and infection}

NL4.3 wild-type (wt) and Env-deleted ( $\Delta$ Env negative control) viruses were produced by transfection of HEK 293T cells with molecular clones using polyethylenimine (PEI) (Polysciences) as described previously. ${ }^{11}$ Vesicular stomatitis virus glycoprotein (VSV-G) pseudotyped NL4.3 virus was made by cotransfection with NL4.3 molecular clone and VSV-G expression vector for infection of Jurkat cells. Supernatant from transfected cells was purified by filtering through $0.45 \mu \mathrm{m}$ filter (Millipore), and NL4.3 and NL4.3- $\Delta$ Env viruses were further concentrated using ultracentrifugation over $20 \%$ sucrose cushion for $75 \mathrm{~min}$ at $28,000 \mathrm{rpm}$. Virus pellets were resuspended in serum- and glucose-free DMEM and virus infectivity was determined by titration on CEM-ss and Jurkat cells with subsequent intracellular p24 ${ }^{\mathrm{Gag}}$ staining and flow cytometry analysis.

Cell samples for the intracellular amino acid level determination, ${ }^{13} \mathrm{C}$-tracing experiments, and western blotting were included for analysis if a minimum $70 \%$ of the cells stained positive for $\mathrm{p} 24^{\mathrm{Gag}}$ cells by flow cytometry at $24 \mathrm{~h}$ postinfection. Uninfected control samples received an equal volume of ultracentrifuge-purified noninfectious $\Delta$ Env NL4.3 virus stock. For NMR experiments with $\mathrm{U}^{13}{ }^{13} \mathrm{C}$-glutamine experiments, samples were included if at least $50 \%$ of the cells stained positive for $\mathrm{p} 24^{\mathrm{Gag}}$ at $24 \mathrm{~h}$ postinfection. Experiments addressing virus replication and caspase 3 activation in glutamine-limiting conditions were performed with cell preparations, wherein $1 \%-$ $10 \%$ of the cells stained positive for p $24^{\mathrm{Gag}}$ at $24 \mathrm{~h}$ after infection, and these were subsequently split into cultures with the indicated glutamine concentrations ranging from 0 to $1 \mathrm{mM}$.

\section{Mass spectrometry}

Cells were washed in phosphate-buffered saline (PBS) three times before pelleting at $1,200 \mathrm{rpm}$ for $10 \mathrm{~min}$. Pellets were then snap frozen over a mixture of $70 \%$ methylated spirit and dry ice and stored at $-80^{\circ} \mathrm{C}$. Once all samples were collected, pellets were thawed, and metabolites were extracted with $200 \mu \mathrm{l} 80 \%$ liquid chromatography-grade methanol (Merck)/ demineralized water that was chilled at $-20^{\circ} \mathrm{C}$. Samples were mixed by vortexing and centrifuged for $10 \mathrm{~min}$ at a maximum speed on a benchtop Eppendorf centrifuge at $4^{\circ} \mathrm{C}$. The liquid phase was collected and transferred to a clean Eppendorf tube, the precipitate was kept to determine the protein content of each sample using a BCA assay. Amino acid concentrations were determined using a Biochrom 30 Amino Acid Analyzer equipped with postcolumn ninhydrin derivatization.

Incorporation of ${ }^{13} \mathrm{C}$-labeling into glutamine, glutamic acid, aspartic acid, and citric acid was assessed by liquid chromatography coupled mass spectrometry (LC-MS/MS) according to the procedure of Mills et al. ${ }^{26}$ Briefly, glutamine, aspartic acid, and glutamic acid were converted into their fluorenylmethyloxycarbonyl (FMOC) derivatives and injected onto the analytical $\mathrm{C}_{18}$ column. Incorporation of ${ }^{13} \mathrm{C}$-labeling into citrate was assessed according to a modified procedure of Blom et al. ${ }^{27}$ The mass spectrometer (AB Sciex 4000 Q-trap) operated in the negative ionization mode, and the isotopomers of glutamine, glutamic acid, aspartic acid, and citric acid were measured by specific mass transitions.

\section{Measurement of protein content}

Cell pellets were resuspended in $500 \mu \mathrm{l}$ lysis buffer containing 5\% Triton-X, 5\% sodium dodecyl sulfate (SDS) and 
$3 \%$ urea, heated at $95^{\circ} \mathrm{C}$ for $10 \mathrm{~min}$, then vortexed and spun at $4^{\circ} \mathrm{C}$ for $10 \mathrm{~min}$ at $400 \times \mathrm{g}$. Once cooled to room temperature, samples were sonicated over ice for $30 \mathrm{~s}$ then rested on bench for $1 \mathrm{~h}$. Protein content was measured with the Pierce BCA Protein Assay Kit (Thermo Fisher Scientific) according to the manufacturer's instructions.

\section{Flow cytometry}

Cells were washed in PBS and treated with TrypLE (both Sigma) to remove surface-bound virus particles, then fixed and permeabilized with Cytofix/Cytoperm (BD Biosciences). Samples were then stained with anti-p24 ${ }^{\mathrm{Gag}}$-RD1 (KC57RD1) (Beckman Coulter) antibody only, or in combination with anti-active caspase 3-FITC antibody (clone C92-605; BD Biosciences) at concentrations and incubation times recommended by the manufacturers.

Surface expression of CD4 was determined by staining with antibody 555347 from BD Biosciences according to the manufacturer's instructions. Cells were then washed in fluorescenceactivated cell sorting (FACS) buffer (PBS with 2\% FBS and $1 \%$ $\mathrm{P} / \mathrm{S}$ ), resuspended in $200 \mu \mathrm{l}$ FACS buffer and acquired on a FACSCantoII machine (BD Biosciences). Absolute cell counts were determined using CountBright beads (Life Technologies) after fixing samples with $4 \%$ paraformaldehyde. Data were analyzed with FlowJo software (TreeStar)

\section{Western blotting}

Cell and supernatant samples were separated by SDSpolyacrylamide gel electrophoresis (SDS-PAGE) on $11 \%$ gel for $\mathrm{p} 24^{\mathrm{Gag}}$ and $15 \%$ gels, according to the size of the target proteins, at $27 \mathrm{~mA}$ per gel. Proteins were transferred onto nitrocellulose membrane overnight at $16 \mathrm{~V}$ and blocked for $1 \mathrm{~h}$ with $1 \%$ fat-free milk in $0.1 \%$ Tween/PBS. Membranes were incubated with primary antibodies at room temperature for at least $1 \mathrm{~h}$.

The following primary antibodies were used: anti-HIV-1 Gag antibody (mouse hybridoma 183-H12-5C supernatantkind gift from Prof. M. Malim), anti-GFPT1 (Abcam AB125069), anti-KGA (Proteintech 20170-1-AP), anti-GAC (Proteintech 19958-1-AP), anti-PPAT (OriGene TA504769S) and anti-HSP90 (Santa Cruz sc-7947). After incubation with primary antibodies, membranes were washed and incubated with secondary antibodies 680RD goat anti-mouse 926-68070 and $800 \mathrm{CW}$ goat anti-rabbit 926-32211 (both LI-COR) at room temperature for $1 \mathrm{~h}$. Membranes were then washed again before visualization with a quantitative LI-COR imager.

\section{Infectivity assay}

TZM-bl indicator cells were plated at $1.5 \times 10^{5}$ per well in a 24-well plate and incubated overnight to reach confluent monolayer. Next day, $100 \mu \mathrm{l}$ of supernatant from cultures was added to each well and incubated for $24 \mathrm{~h}$. Media were then aspirated and cells were lysed using $100 \mu \mathrm{l}$ Galacto-Star Lysis solution (Applied Biosciences). Cell lysates were kept at $-20^{\circ} \mathrm{C}$ and thawed on the day of analysis. Once all samples were collected, $\beta$-galactosidase activity was determined with the Galacto-Star Reporter Assay Kit (Applied Biosciences) according to the manufacturer's instructions, and luminescence was measured with Victor ${ }^{\mathrm{TM}}$ Luminometer (PerkinElmer). Values of negative control wells were deducted to account for any autoluminescence present in TZM-bl cells.

\section{p24 enzyme-linked immunosorbent assay}

Samples were diluted 1:500 in $0.5 \%$ Triton, then p24 protein levels were measured using the Alliance HIV-1 p24 Antigen ELISA (enzyme-linked immunosorbent assay) Kit according to the manufacturer's instructions (PerkinElmer). Plates were read on a Bio-Rad plate reader set to dual wavelength at 405 and $630 \mathrm{~nm}$.

\section{NMR analysis}

Metabolite efflux was evaluated by NMR. After infection of cells with HIV-1 for $24 \mathrm{~h}$, culture medium was replaced with fresh DMEM from powder formulation (Sigma) supplemented with $2 \mathrm{mM} \mathrm{U}-{ }^{13} \mathrm{C}$-glutamine. At specific time intervals (1, 2, 3, and $24 \mathrm{~h}), 0.5 \mathrm{ml}$ aliquots were collected from the culture medium to evaluate ${ }^{13} \mathrm{C}$-metabolites efflux into the culture medium. The same volume of medium was replaced to achieve a constant $\mathrm{U}^{13} \mathrm{C}$-glutamine "pulse" during the experiment.

The $0.5 \mathrm{ml}$ of harvested supernatant was mixed with $1.1 \mathrm{ml}$ $100 \%$ prechilled methanol to precipitate proteins. Samples were pipette mixed, vortexed, and spun at 14,000 rpm for $15 \mathrm{~min}$ at $4^{\circ} \mathrm{C}$. Clear extracts were transferred into new tubes and dried in a vacuum concentrator (Eppendorf). Samples were resuspended in $600 \mu 150 \mathrm{mM}$ sodium phosphate buffer containing $10 \%$ deuterated water $\left({ }^{2} \mathrm{H}_{2} \mathrm{O}\right), \mathrm{pH}$ 7.0. To evaluate the kinetics metabolites efflux, one-dimensional ${ }^{13} \mathrm{C}$ spectra were obtained at $298 \mathrm{~K}$, using $45^{\circ}$ pulses with a repetition time of $0.6 \mathrm{~s}, 16,000$ complex points, 2,028 scans, and a spectral width of 200 p.p.m. The free-induction decays were zero filled to 16,384 points and apodized with exponential multiplication using line broadening of $10 \mathrm{~Hz}$. Spectra were acquired with a Bruker Advance $500 \mathrm{MHz}$ instrument.

Spectral processing and analysis was performed using Topspin 3.5. Glutamine and other metabolites were assigned using the Human Metabolome Database v $3.6^{28}$ and quantified by their peak integrals. For glutamine, as well as glutamic acid, carbons 3 and 4 have the highest intensity peaks in the ${ }^{13} \mathrm{C}$ NMR spectra and these were therefore used for quantification. The highest intensity peak for lactic acid was carbon 3 .

\section{Statistics}

GraphPad Prism software was used to perform two-tailed $t$-test to calculate $p$-values.

\section{Results}

\section{HIV-1 replication and $C D 4^{+} T$ lymphocyte viability are dependent on glutamine}

To identify differences between uninfected and HIV-1infected primary human $\mathrm{CD} 4^{+} \mathrm{T}$ cells with regard to amino acid metabolism, we analyzed cell lysates for amino acid content on a Biochrom 30 Amino Acid Analyzer (Fig. 1). Primary $\mathrm{CD}^{+} \mathrm{T}$ cells were activated with anti-CD3/CD28coated beads in the presence of IL- 2 and infected with the virus stocks of HIV-1 NL4.3 molecular clone at high multiplicity of infection for $48 \mathrm{~h}$, such that at least $70 \%$ of the cells were positive by intracellular staining for the HIV-1 p $24^{\mathrm{Gag}}$ protein by flow cytometry (not shown). Control cells were treated with an equivalent inoculum of Env-deleted noninfectious NL4.3 $\Delta$ Env and accordingly showed no expression of $\mathrm{p} 24^{\mathrm{Gag}}$. Samples were normalized to the protein content in 

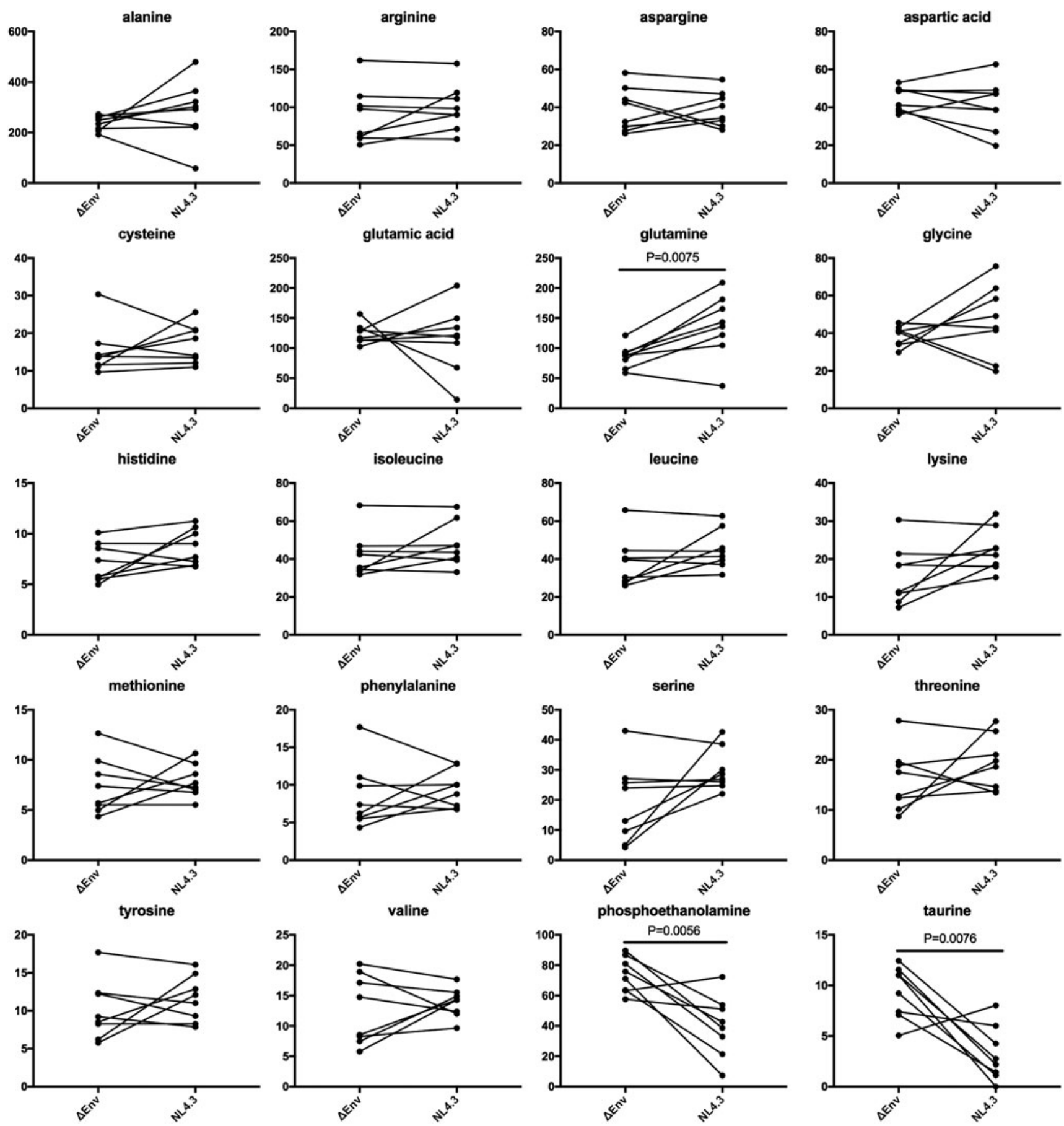

FIG. 1. Intracellular amino acid content of HIV-1-infected versus uninfected primary human CD4 ${ }^{+} \mathrm{T}$ cells. Scales on the Y-axis indicate the intracellular concentration of each amino acid, as indicated at the top of individual plots, in micromolar per milligram of protein in the corresponding cell sample. Uninfected cells were inoculated with an Env-deleted $(\Delta E n v)$ preparation of HIV-1 NL4.3 corresponding to the same amount of p24 ${ }^{\text {Gag }}$ of wild-type NL4.3 that was added to the infected samples (NL4.3). Glutamine emerged as the only proteinogenic amino acid that showed a statistically significant elevated concentration in the infected cells with $p=.0075$. Phosphoethanolamine and taurine were significantly reduced in abundance in the HIV-1-infected versus uninfected cells $(\Delta$ Env). HIV-1, human immunodeficiency virus type 1.

each sample as determined with the BCA assay of the methanol precipitate of the cells.

Analysis of amino acid abundance revealed that the intracellular concentration of glutamine was significantly elevated in the HIV-1 NL4.3-infected cells compared with the uninfected controls. Although there was a tendency toward elevated concentrations of other amino acids such as leucine, serine, and lysine in the HIV-1-infected cells, none of these reached statistical significance. In addition, a trend toward reduced intracellular concentrations of glutamic acid was observed, but this was also not statistically significant (Fig. 1). 
In addition to the proteinogenic amino acids, the amino acid analysis also detected the presence of the sulfonic acid taurine and the polyprotic acid phosphorylethanolamine. Both these compounds were significantly reduced in abundance in the lysate of HIV-1 NL4.3-infected cells compared with uninfected cells, demonstrating that normalization to protein content in the samples did not introduce a bias toward increased amino acid abundance in the infected samples. Therefore, HIV-1-infected primary human $\mathrm{CD}^{+} \mathrm{T}$ cells have a higher intracellular glutamine concentration than uninfected cells and lower concentrations of taurine and phosphorylethanolamine.

Because glutamine is one of the major metabolic resources that $\mathrm{CD}^{+}{ }^{+} \mathrm{T}$ cells require for survival, proliferation, and effector function, ${ }^{1,2}$ we sought to investigate the dependency of HIV-1 replication on this amino acid. Spreading HIV-1 NL4.3 infections were monitored in cultures of activated human $\mathrm{CD} 4^{+}$ $\mathrm{T}$ lymphocytes in the presence of titrated amounts of supplemented glutamine at 1.0, 0.5, 0.2, and $0 \mathrm{mM}$. To ensure that the infection was identical for each condition, we inoculated a culture containing $1.0 \mathrm{mM}$ glutamine with HIV-1 NL4.3 for $24 \mathrm{~h}$, after which the cells were washed with PBS to remove glutamine replete media and the cells were then split into media with the titrated glutamine concentrations.

We note that we used dialyzed serum to minimize the amount of glutamine introduced into the culture by the addition of FBS, but it is likely that the cultures with no added glutamine would still contain trace amounts of this amino acid from the FBS.

We assessed several parameters in these cultures: the amount of HIV-1 p24 ${ }^{\mathrm{Gag}}$ released into the culture by ELISA, infectious virus in the culture supernatant using the TZM-bl indicator cell line, and the proportion of cells expressing $\mathrm{p} 24^{\mathrm{Gag}}$, as well as the apoptotic marker activated caspase 3 by flow cytometry. The infectivity of the culture supernatant (Fig. 2A) as well as the amount of released p24 ${ }^{\mathrm{Gag}}$ (Fig. 2B) consistently decreased with lower glutamine concentrations, as is shown for a representative experiment in Figure 1.

In the absence of any added glutamine, neither $\mathrm{p} 24^{\mathrm{Gag}}$ in the culture nor the production of infectious virions was detected. In correlation with the reduced viral output at limiting glutamine concentrations and upon glutamine starvation, the proportion of cells in the culture that expressed the $\mathrm{p} 24^{\mathrm{Gag}}$ protein was reduced to $\sim 70 \%$ at $0.2 \mathrm{mM}$ glutamine and $30 \%$ at $0 \mathrm{mM}$ glutamine of the values obtained at $1 \mathrm{mM}$ glutamine after $24 \mathrm{~h}$ of the provision of the limiting glutamine concentrations (Fig. 2C, D). This suggests that HIV-1-infected $\mathrm{CD}^{+} \mathrm{T}$ cells are more dependent on glutamine for survival than uninfected cells.

The flow cytometry analysis of intracellular activated caspase 3 furthermore demonstrated that glutamine is required for $\mathrm{T}$ cell viability as caspase 3 activation remained stable in cultures containing $1.0,0.5$, and $0.2 \mathrm{mM}$ added glutamine, but it was elevated in the glutamine-starved culture. This was observed in both infected and uninfected cultures (Fig. 2D). While these data indicate that HIV-1 replication is dependent on glutamine, we were unable to unequivocally dissect the effect of glutamine starvation on virus replication from effects on cell physiology.

\section{Tracking the fate of glutamine in HIV-1-infected} and uninfected cells with ${ }^{13} \mathrm{C}$-stable isotope labeling

Apart from acting as a proteinogenic amino acid, glutamine also has an important role in anaplerotically driving the citric acid cycle in cells that do not use glycolysis-derived pyruvate to support oxidative phosphorylation. Indeed, $\mathrm{T}$ cells are known to significantly utilize glutamine in this manner. ${ }^{2}$ To assess the origin of carbon in the citric acid cycle in HIV-1-infected and uninfected cells, we supplemented HIV-1 NL4.3 wt and $\Delta$ Env inoculated cultures after $24 \mathrm{~h}$ with a $1: 1$ ratio of ${ }^{12} \mathrm{C} /{ }^{13} \mathrm{C}$ glutamine $\left(\mathrm{Gln}-3-{ }^{13} \mathrm{C}\right)$ or pyruvate (Pyr-2- ${ }^{13} \mathrm{C}$ ) and incubated for a further $24 \mathrm{~h}$.

We confirmed that the cells had been infected to a high MOI, with a minimum of $70 \%$ of the cells containing intracellular HIV-1 p $24^{\text {Gag }}$ (not shown). We included cultures of the T cell lines Jurkat and CEM-ss that were infected and supplemented with ${ }^{12} \mathrm{C} /{ }^{13} \mathrm{C}$ glutamine or pyruvate in the same manner. Jurkat cells were infected with a VSV-G-pseudotyped HIV-1 NL4.3 preparation to achieve the high percentage of infected cells. Upon extraction of the intracellular metabolites, we analyzed the percentage of ${ }^{12} \mathrm{C}$ and ${ }^{13} \mathrm{C}$ present in glutamine, glutamic acid, aspartic acid, and citric acid by LC-MS.

Glutamic acid is an important intermediate for entry of glutamine into the citric acid cycle as $\alpha$-ketoglutarate, which is driven by sequential action of the glutaminase and glutamate dehydrogenase or glutamate transaminase enzymes. Aspartic acid can be derived from and converted to oxaloacetate by glutamate oxaloacetate transaminase and serves as an indirect read out of the carbon content of the citric acid cycle. Citric acid, likewise, provides an indirect measure of the relative amounts of ${ }^{12} \mathrm{C}$ and ${ }^{13} \mathrm{C}$ present in the citric acid cycle derived from glutamine or pyruvate, as it can also be generated from acetyl-CoA through fatty acid oxidation.

The analysis of ${ }^{13} \mathrm{C}$ enrichment in glutamine confirmed that the intracellular concentrations reflected the 1:1 ratio (or 50\% ${ }^{13} \mathrm{C}$ ) of ${ }^{12} \mathrm{C}$ - to ${ }^{13} \mathrm{C}$-containing glutamine that we supplemented the cultures with (Fig. 3A). In addition, we observed only very low amounts of ${ }^{13} \mathrm{C}$-labeled glutamine, glutamic acid, aspartic acid, and citric acid in cultures that had been provided with the 1:1 mixture of ${ }^{12} \mathrm{C} /{ }^{13} \mathrm{C}$-containing pyruvate, confirming that very little pyruvate enters the citric acid cycle in $\mathrm{T}$ cells. This was unaffected by infection of either primary $\mathrm{CD} 4^{+} \mathrm{T}$ cells or the T cell lines, CEM-ss and Jurkat, with HIV-1 NL4.3.

We also observed that the glutamic acid contained $\sim 45 \%$ of ${ }^{13} \mathrm{C}$ (Fig. 3B), demonstrating that the majority of the intracellular glutamic acid is derived from glutamine $(\sim 90 \%)$. Aspartic acid and citric acid contained an average of $35 \%$ of ${ }^{13} \mathrm{C}$ (Fig. 3C, D, respectively), again demonstrating that the majority of carbon in the citric acid cycle is derived from glutamine in T cells.

A clear difference in ${ }^{13} \mathrm{C}$ enrichment in glutamic acid was observed between the primary $\mathrm{CD}^{+} \mathrm{T}$ cells and the cell lines after infection with HIV-1. While the $45 \%{ }^{13} \mathrm{C}$ content was unaffected in HIV-1 NL4-3-infected primary CD4 ${ }^{+} \mathrm{T}$ cells, it was reduced to $\sim 35 \%$ in CEM-ss and Jurkat cells (Fig. 3B). A similar reduction was observed with the cell lines upon the analysis of ${ }^{13} \mathrm{C}$ enrichment in aspartic and citric acid, indicating that the utilization of glutamine as a substrate for the citric acid cycle is reduced upon infection of the T cell lines, CEM-ss and Jurkat (Fig. 3C, D). The ${ }^{13} \mathrm{C}$ enrichment of aspartic acid and citric acid was unaffected by the infection of primary $\mathrm{CD}^{+}{ }^{+} \mathrm{T}$ cells with HIV-1.

These observations are in line with our previous studies, in which we monitored the lactic acid production and oxygen consumption of infected primary $\mathrm{CD}^{+} \mathrm{T}$ cells as well as CEM-ss and Jurkat cells. ${ }^{11}$ Those analyses indicated that 

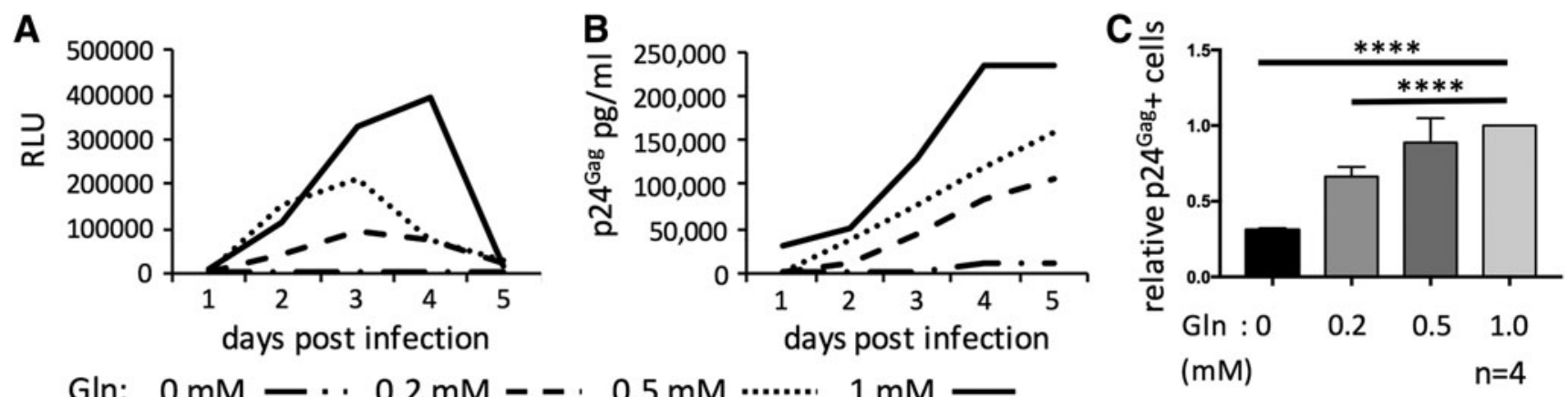

Gln: $0 \mathrm{mM}-\cdots 0.2 \mathrm{mM}--\cdot 0.5 \mathrm{mM} \cdots \cdots \cdot 1 \mathrm{mM}-$

Gln: $\quad 0 \mathrm{mM}$

$0.2 \mathrm{mM}$

$0.5 \mathrm{mM}$

$1 \mathrm{mM}$
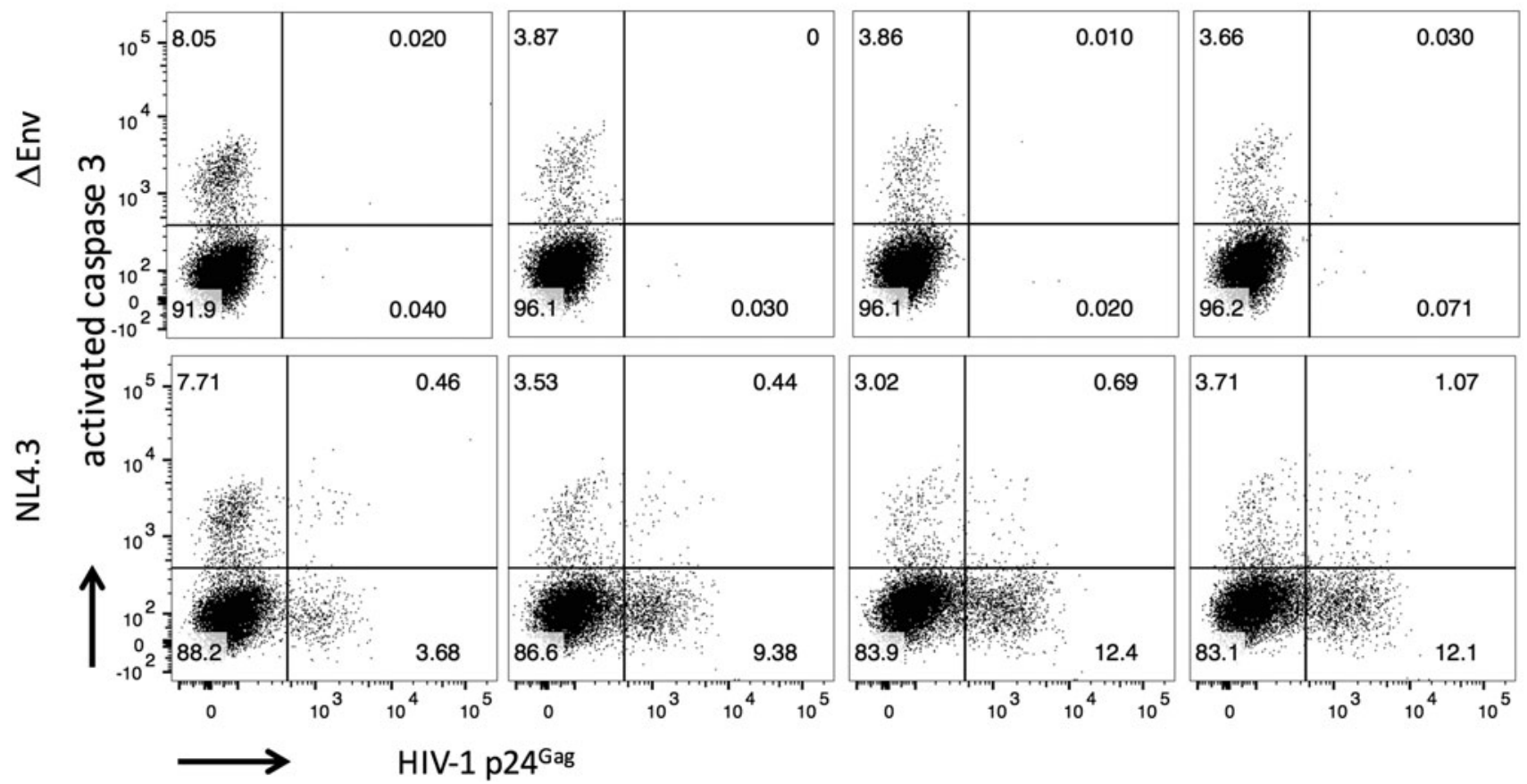

FIG. 2. The effect of limiting glutamine concentrations on HIV-1 replication and caspase 3 activation. (A) An HIV-1 spreading infection in a culture of activated human $\mathrm{CD}^{+} \mathrm{T}$ cells at limiting glutamine concentrations as monitored by infectivity of the culture supernatant using the TZM-bl indicator cell line. The scale on the Y-axis in RLU indicates relative luciferase units that are an indirect measure for HIV-1 infectivity as the TZM-bl cells contain the luciferase gene under the control of the HIV-1 LTR promoter. (B) The HIV-1 p24 ${ }^{\mathrm{Gag}}$ concentration (pg/ml) in the cultures shown in (A) as determined by ELISA. (C) The amounts of p24Gag-expressing cells in cultures with limiting glutamine (Gln) concentrations relative to p24Gag-expressing cells at $1.0 \mathrm{mM}$ glutamine. (D) Representative determination of the intracellular abundance of activated caspase 3 (Y-axis) and HIV-1 p24 ${ }^{\mathrm{Gag}}$ in HIV-1 infected (NL4.3) and uninfected ( $\Delta$ Env) cultures of activated primary human $\mathrm{CD} 4^{+} \mathrm{T}$ cells at limiting concentrations of glutamine by flow cytometry. Numbers in the corners of each quadrant indicate the percentage of cells that stained singly positive for caspase 3 or p24 ${ }^{\mathrm{Gag}}$, cells that were double positive or negative. Statistical significance is indicated by asterisks with $* * * * p \leq .0001$. ELISA, enzyme-linked immunosorbent assay.

oxygen consumption of primary cells is unaffected by infection with HIV-1 and that CEM-ss and Jurkat cells show very different metabolic responses to HIV-1 infection than primary $\mathrm{CD}^{+} \mathrm{T}$ cells do in that their oxidative metabolism is reduced on infection with HIV-1. Importantly, these analyses demonstrate that in primary human $\mathrm{CD}^{+} \mathrm{T}$ cells, glutamine is the principal source of intracellular glutamic acid and the primary substrate of the citric acid cycle. This is unaffected by infection of the primary $\mathrm{CD}^{+}{ }^{+} \mathrm{T}$ cells with HIV-1 NL4.3.

Having investigated the intracellular fate of glutamine in infected primary $\mathrm{T}$ cells, we next sought to interrogate the glutamine-derived exometabolome (the secreted metabolites) of uninfected and infected primary $\mathrm{CD}^{+} \mathrm{T}$ cells. For this purpose, we again established highly infected cultures and supplemented these, as well as the uninfected controls, with uniformly ${ }^{13} \mathrm{C}$-labeled glutamine after $24 \mathrm{~h}$ of infection. Aliquots of the supernatant from these cultures were harvested over a time course of an additional 1, 2, 3, and $24 \mathrm{~h}$ after the supplementation with ${ }^{13} \mathrm{C}$-glutamine and these samples were subjected to ${ }^{13} \mathrm{C}$ NMR analysis (Fig. 4A, B).

The $\mathrm{C} 3$ and $\mathrm{C} 4$ carbon peaks for glutamine were readily identifiable and confirmed as the highest intensity peaks for 
A

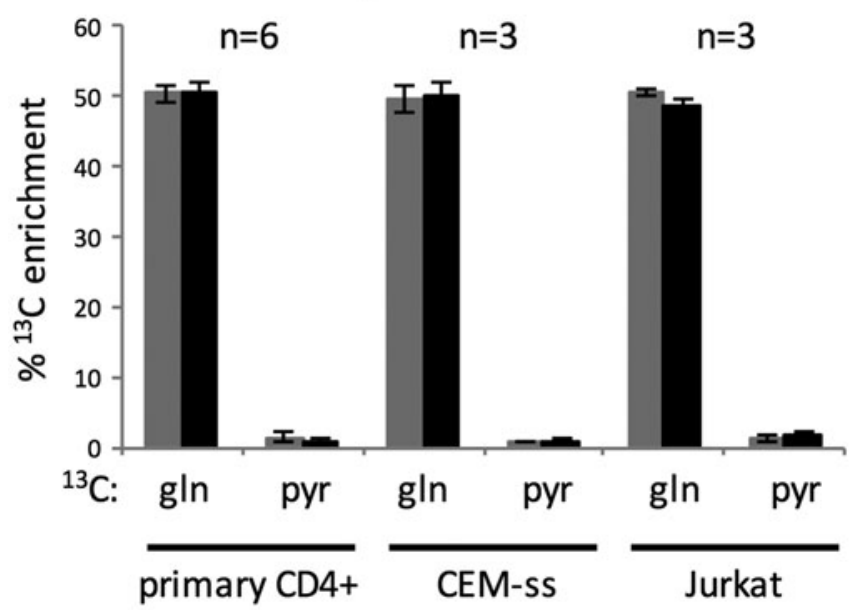

C

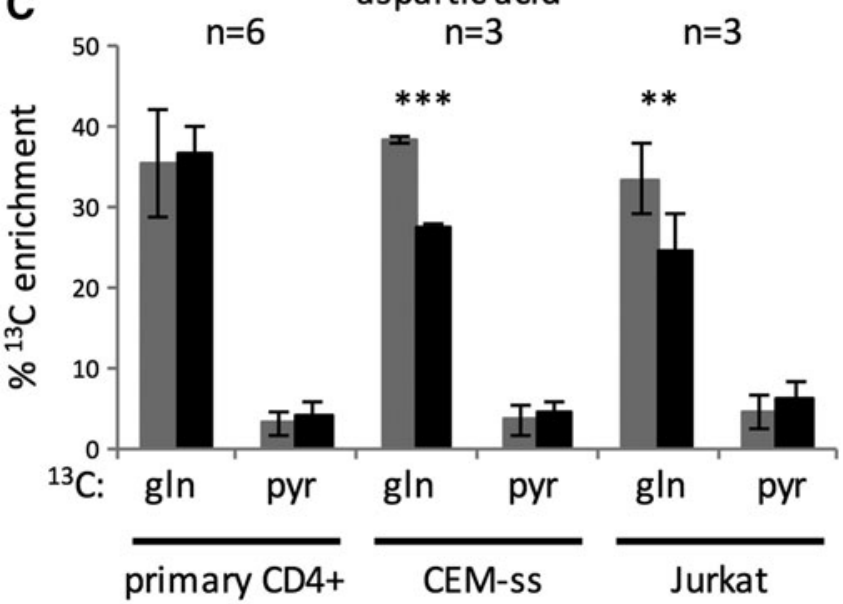

B

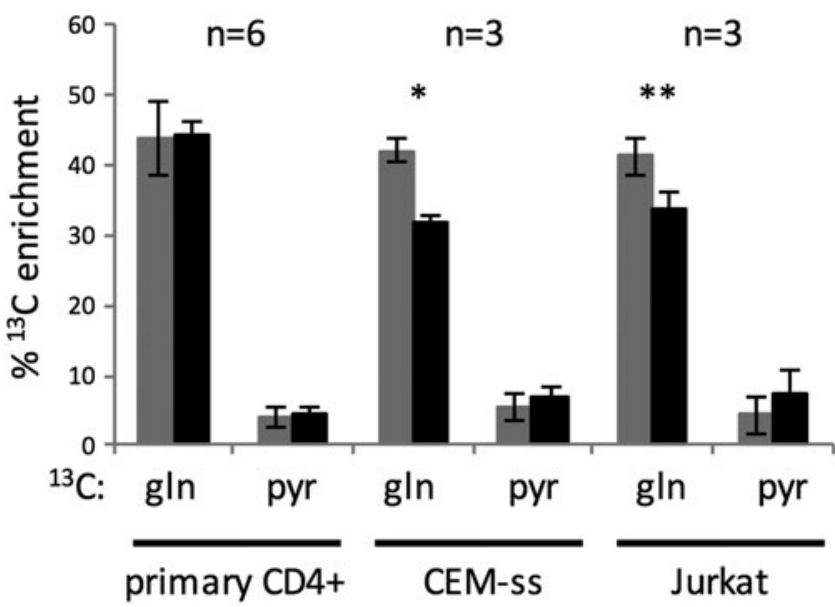

D

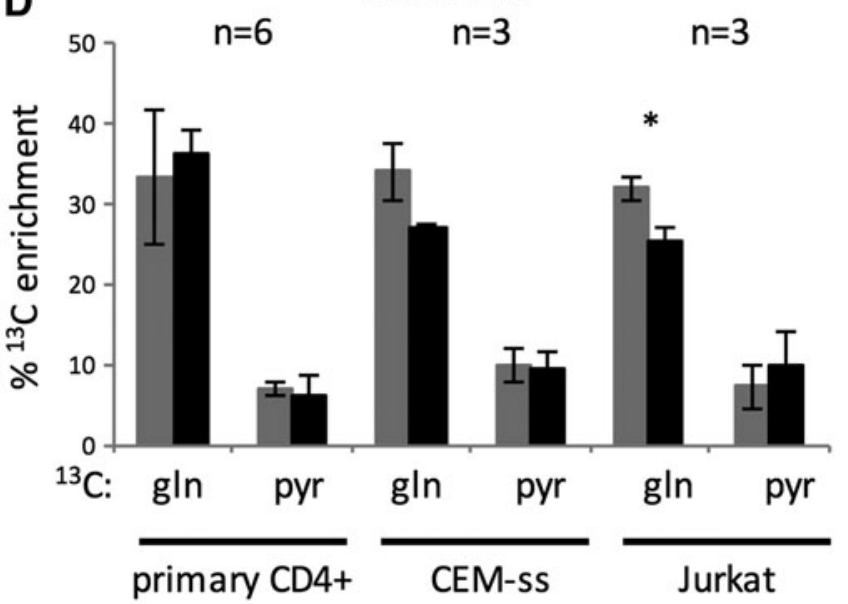

\section{$\Delta$ Env $\quad$ HIV-1 NL4.3}

FIG. 3. Metabolic tracing of the fate of intracellular glutamine in HIV-1-infected and uninfected $\mathrm{T}$ cells by ${ }^{13} \mathrm{C}$ enrichment mass spectrometry analysis. Cells cultured in media containing a $1: 1$ ratio of ${ }^{12} \mathrm{C}$ to ${ }^{13} \mathrm{C}$ mono-labeled glutamine or pyruvate, as indicated on the $\mathrm{X}$-axis. The percentage of ${ }^{13} \mathrm{C}$ was determined by mass spectrometry for cell-extracted glutamine (A), glutamic acid (B), aspartic acid (C), and citric acid (D). The experiments were performed with six different donors for activated primary human $\mathrm{CD}^{+} \mathrm{T}$ cells as well as three independent replicates of the cell lines CEM-ss and Jurkat. Jurkat cells were infected with VSV-G-pseudotyped HIV-1. Statistical significance is indicated by asterisks with $* p \leq .05, * * p \leq .01$, and $* * * p \leq .001$. VSV-G, vesicular stomatitis virus glycoprotein.

the carbons in glutamine with control spectra. As the time course progressed, peaks for carbons 3 and 4 of glutamic acid and carbon 3 for lactic acid started to appear in the spectra that were also identified by the use of reference spectra. Interestingly, the signal for glutamic acid was more prominent and occurred at earlier time points in the infected compared with the uninfected cultures (Fig. 4A). By $24 \mathrm{~h}$ after supplementation with ${ }^{13} \mathrm{C}$ glutamine, it was evident that the concentration of ${ }^{13} \mathrm{C}$ glutamic acid was significantly higher in the infected cultures (Fig. 4B).

Conversely, the concentration of ${ }^{13} \mathrm{C}$ lactate was reduced in infected compared with uninfected cultures (Fig. 4B). These results indicate increased secretion of glutaminederived glutamic acid and decreased secretion of glutaminederived lactic acid from infected versus uninfected primary $\mathrm{CD}^{+} \mathrm{T}$ cells. Because we detected no signal for other ${ }^{13} \mathrm{C}$ - labeled compounds, this rules out the possibility that infection-induced cell lysis is responsible for the observed changes in glutamic and lactic acid concentrations in the culture supernatants. We, therefore, conclude that infection of primary $\mathrm{CD}^{+} \mathrm{T}$ cells with HIV-1 results in an increased secretion of glutamine-derived glutamic acid and decreased secretion of glutamine-derived lactic acid.

\section{Differential expression of glutamine-metabolizing enzymes upon infection with HIV-1}

Since we observed differential secretion of glutaminederived metabolites from HIV-1-infected and uninfected cells, we sought to establish whether this coincided with differential expression of enzymes that act on glutamine. Owing to the important and diverse roles that glutamine plays 
FIG. 4. Metabolic tracing of the fate of $\mathrm{U}_{-}{ }^{13} \mathrm{C}$-labeled glutamine in the supernatant of HIV-1-infected and uninfected activated primary human $\mathrm{CD}^{+} \mathrm{T}$ cells by NMR. (A) Time course NMR analyses of the supernatant of HIV-1-infected (HIV-1 NL4.3) and uninfected $(\Delta \mathrm{Env})$ cultures at $1 \mathrm{~h}$ (black), $2 \mathrm{~h}$ (blue), $3 \mathrm{~h}$ (red), and $24 \mathrm{~h}$ (gray) postinfection. Peaks corresponding to the carbons 3 and 4 of glutamic acid as well as carbon 3 of lactic acid are indicated above the spectra. The cluster of peaks at $\sim 34$ and $29 \mathrm{ppm}$ on the $\mathrm{X}$-axis correspond the carbons 3 and 4 of the $\mathrm{U}^{13} \mathrm{C}$ labeled glutamine that was provided to the cultures. (B) Quantification of the glutamine, glutamic acid, and lactic acid abundance in the culture supernatant at $24 \mathrm{~h}$ postinfection as determined by NMR analysis of five different donors. Statistical significance is indicated by an asterisk with $* p \leq .05$. NMR, nuclear magnetic resonance.

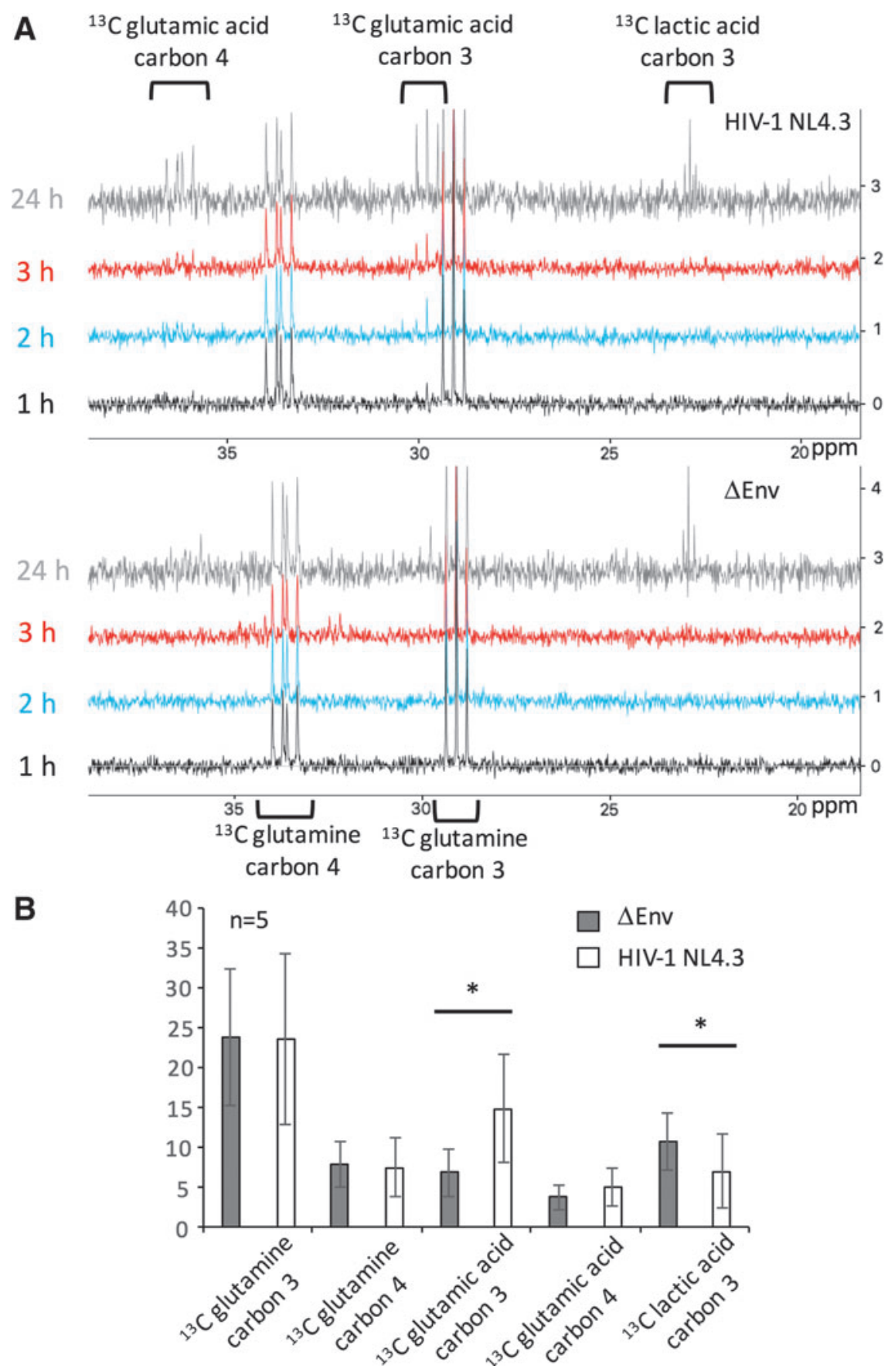

in metabolism and protein synthesis, there are a considerable number of enzymes and transporters that are involved in glutamine metabolism. We focused our western blotting analysis on enzymes that act on glutamine to produce glutamic acid (Fig. 5A, B) and acquired the corresponding commercially available antibodies.

We were able to detect the glutaminase isoforms, KGA and GAC, as well as the enzymes PPAT and GFPT1 (see Fig. 5C for their reaction mechanisms), for which commercially available antibodies proved functional in our studies. PPAT is the enzyme committing glutamine-derived nitrogen to de novo purine synthesis and GFPT1 is the first as well as the ratelimiting enzyme in the hexosamine pathway. We generated human primary $\mathrm{CD}^{+} \mathrm{T}$ cell samples that were at least $70 \%$ infected with HIV-1 NL4.3 as determined by flow cytometry of intracellular p24 $4^{\mathrm{Gag}}$ (not shown) and the corresponding uninfected samples that were inoculated with HIV-1 $\Delta$ Env.

After $48 \mathrm{~h}$ of infection, live cells in the culture were counted and samples corresponding to equal live cell counts for HIV-1-infected and uninfected conditions were analyzed by SDS-PAGE and western blotting. After further normalization to the quantity of HSP90 protein in each sample, it emerged that the glutaminase isoform GAC was consistently downregulated in the HIV-infected samples compared with uninfected cells (Fig. 5A), and this was statistically significant over multiple quantified experiments (Fig. 5B). Furthermore, an immunoreactive band of lower molecular weight was consistently observed in the HIV-1-infected 
A
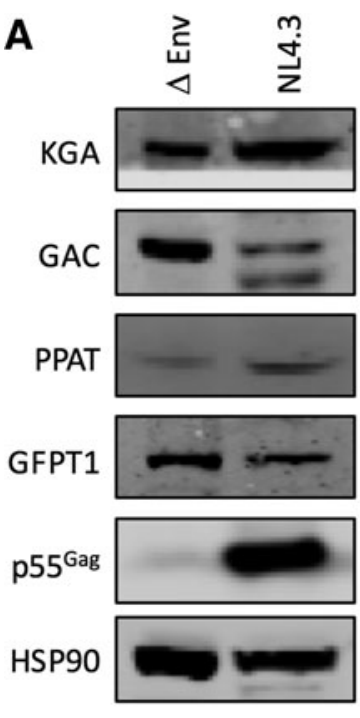
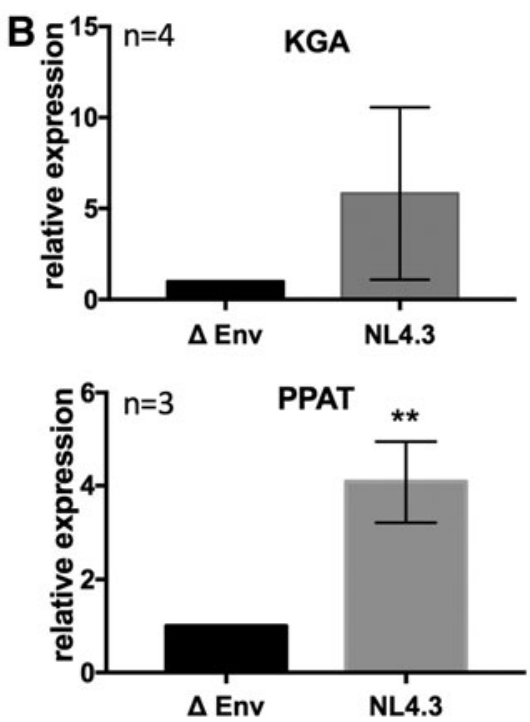
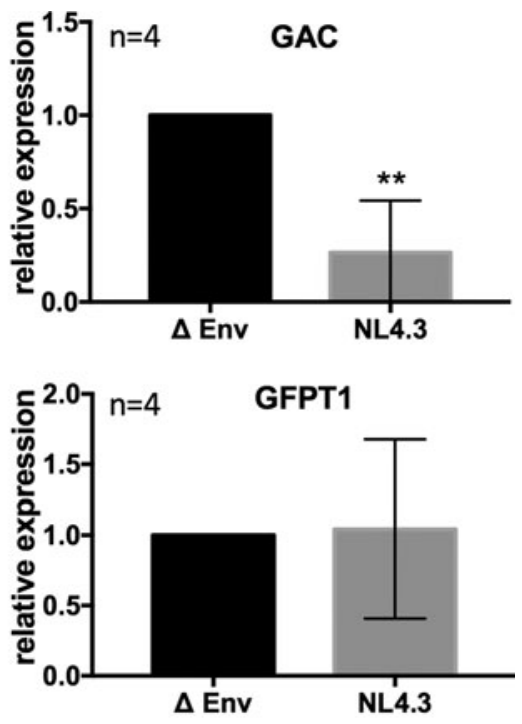

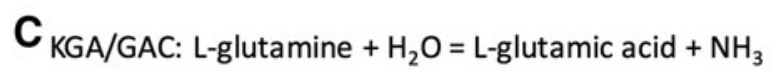

PPAT: L-glutamine +5 -phospho- $\alpha$-D-ribose 1-diphosphate $+\mathrm{H}_{2} \mathrm{O}=$

5-phospho- $\beta$-D-ribosylamine $+\mathrm{PPi}+$ L-glutamic acid

GFPT1: L-glutamine + D-fructose 6-phosphate = L-glutamic acid + D-glucosamine 6-phosphate

FIG. 5. The expression of glutamine-metabolizing enzymes in HIV-infected and uninfected activated primary human $\mathrm{CD}^{+} \mathrm{T}$ cells as determined by western blotting. (A) Representative western blots showing the expression of HSP90 (loading control), KGA, CAG (both glutaminase isoforms), PPAT, GFPT1, and p24 ${ }^{\text {Gag }}$ in uninfected ( $\Delta$ Env) and infected (NL4.3) cells at $48 \mathrm{~h}$ postinfection. (B) Quantified data from (A), relative to HSP90 expression and normalized to the uninfected $\Delta$ Env control samples. (C) Reactions catalyzed by the KGA, CAG, PPAT, and GFPT1 enzymes. Statistical significance is indicated by asterisks with ** $\leq .01$.

samples, which may correspond to a degradation product or modified form of GAC (Fig. 5A).

Furthermore, we consistently observed increased expression of the glutaminase isoform KGA as well as the enzyme PPAT in the HIV-1-infected compared with uninfected samples, although this only reached statistical significance with the quantified data for PPAT (Fig. 5A, B). Expression levels of GFPT1 were unaffected by the HIV-1 infection. We also confirmed that the liver-specific isoform of glutaminase, GLS2, is not expressed in HIV-1-infected and uninfected T cells (not shown). While it is not possible to draw conclusions as to the overall effect of HIV-1 infection on the cellular glutamine metabolism from the expression levels of these enzymes alone, our results do demonstrate that there are considerable changes in the expression of several enzymes acting on glutamine upon infection of primary human $\mathrm{CD}^{+}{ }^{+} \mathrm{T}$ cells with HIV -1 .

\section{Discussion}

In this study, we have investigated the effect of HIV-1 infection on the glutamine metabolism of primary human $\mathrm{CD}^{+} \mathrm{T}$ cells. We report four key observations: (1) HIV-1infected primary $\mathrm{CD}^{+} \mathrm{T}$ cells contain higher glutamine concentrations than uninfected cells; (2) entry of glutamine into the citric acid cycle is unaffected by HIV-1 infection of primary $\mathrm{CD}^{+} \mathrm{T}$ cells; (3) the secretion of glutamic acid is increased upon infection with HIV-1; and (4) the expression of several enzymes that act on glutamine is responsive to HIV-1 infection. These changes in the glutamine metabolism may either serve to support the HIV-1 infection cycle or represent a cellular response to the infection; we have been unable to unequivocally assign this distinction. Nonetheless, these changes in glutamine metabolism are clearly hallmarks of HIV-1 infection in primary human $\mathrm{CD} 4^{+} \mathrm{T}$ cells.

Indeed, a recent study of the serum metabolome of HIV-1infected individuals showed that glutamine as well as glucose concentrations were inversely correlated with $\mathrm{CD} 4^{+} \mathrm{T}$ cell count, suggesting a physiological link between glutamine and glucose metabolism with HIV disease progression. ${ }^{29}$ Intriguingly, the same was not observed in a cohort of young (below 18 years of age) HIV-infected individuals, who maintained similar serum concentrations of glutamine and glutamate as healthy individuals. ${ }^{30}$ The reasons for this difference currently remain unclear.

As regards the increased concentration of glutamine in HIV-1-infected primary cells (Fig. 2), we consider it most likely that this is due to increased glutamine uptake by the cells. Indeed, we did attempt to address this by classical glutamine uptake assays using radio-labeled glutamine, but these experiments lacked the sensitivity to discern a quantifiable difference in glutamine uptake by HIV-1-infected and uninfected cells (not shown). However, the metabolic tracer experiments monitoring the intracellular fate of ${ }^{13} \mathrm{C}$-labeled glutamine provide indirect evidence that the increase in intracellular glutamine is likely to be due to increased uptake. As the intracellular glutamine pool maintained a $50 \%$ ratio of ${ }^{13} \mathrm{C}$ to ${ }^{12} \mathrm{C}$ that was provided in the culture media, there was clearly no significant intracellular synthesis of glutamine. 
Increased intracellular synthesis of glutamine would have been evident as a reduction in the proportion of cytoplasmic ${ }^{13} \mathrm{C}$-containing glutamine. Conversely, import of glutamine would maintain the $1: 1$ ratio of ${ }^{13} \mathrm{C}$ to ${ }^{12} \mathrm{C}$, as we did indeed observe (Fig. 3A).

Glutamine transport can be mediated by a variety of proteins from the solute carrier-type transporter superfamily with directionality that can be either influx, efflux, or both. ${ }^{31,32}$ Glutamine transport into $\mathrm{T}$ cells remains incompletely understood as regards transporter identity, substrate specificity, and directionality. ${ }^{33}$

It has long been appreciated that glutamine is required to support $\mathrm{T}$ cell activation, including the expression of $\mathrm{CD} 45$, CD71, and IFN $\gamma \cdot{ }^{34}$ In addition, CD98 consists of SLC7A5 and SLC3A2 subunits that export glutamine in exchange for importing leucine (and other branched amino acids) to drive mammalian target of rapamycin (mTOR) activation ${ }^{35}$ and its role in T cell activation is well documented. ${ }^{36-38}$ More recently, it was shown that $\mathrm{T}$ cell activation leads to the increased expression of several potential glutamine transporters and other metabolite transporters ${ }^{39}$ in a Mycregulated manner. ${ }^{40,41}$

The glutamine transporter SLC1A5 (ASCT2) has been shown to support murine effector $\mathrm{CD}^{+} \mathrm{T}$ cell differentiation and is necessary for early phase glutamine uptake after TCR stimulation and costimulation. ${ }^{42}$ However, after prolonged activation, glutamine uptake into murine $\mathrm{SLC} 1 \mathrm{~A} 5^{-1-} \mathrm{CD} 4^{+} \mathrm{T}$ lymphocytes was apparent, indicating that other glutamine transporter must be active in $\mathrm{CD} 4^{+} \mathrm{T}$ cells.

In the context of HIV-1 infection, the transporter SLC38A1 (or SNAT1) that was originally annotated as a neuronal glutamine transporter ${ }^{43}$ was recently shown to be downregulated by the HIV-1 Vpu protein and was shown to mediate alanine, but not glutamine, uptake into T cells. ${ }^{44}$ Therefore, there remain many open questions as regards the identity as well as activity of glutamine transporters ${ }^{33,45}$ and their regulation during T cell activation and HIV-1 infection.

Our current observation that entry of glutamine-derived carbon into the citric acid cycle is unaffected by infection of primary $\mathrm{CD} 4^{+} \mathrm{T}$ cells with HIV-1 is in line with our previous study. ${ }^{11}$ We previously reported that HIV-1-infected primary $\mathrm{CD}^{+} \mathrm{T}$ cells show increased glycolysis and lactic acid production compared with uninfected cells, but mitochondrial oxygen consumption remained unaffected. ${ }^{11}$ In that same study, we also reported that, unlike primary $\mathrm{CD} 4^{+} \mathrm{T}$ cells, the $\mathrm{T}$ cell lines, CEM-ss and Jurkat, have reduced oxygen consumption rates upon infection with HIV-1. Our current experiments showing reduced entry of glutamine-derived carbon into the citric acid cycle corroborate those findings, as evidenced by lower ${ }^{13} \mathrm{C}$ percentages present in glutamic acid, aspartic acid, and citric acid for CEM-ss and Jurkat cells (Fig. 3).

Investigation of the exometabolome of HIV-1-infected and uninfected primary $\mathrm{CD}^{+} \mathrm{T}$ cell cultures (Fig. 4) revealed a faster and greater secretion of glutamine-derived glutamic acid by HIV-1-infected cells. As the majority of intracellular glutamic acid (at least 90\%, see Fig. 3A, B) is derived from glutamine, this implies a greater net efflux of glutamic acid from HIV-1-infected primary CD4 ${ }^{+} \mathrm{T}$ cells. The concomitant reduction in the proportion of glutamine-derived lactic acid (Fig. 4B) may be explained by the greater glucose-derived lactic acid production that we and others have previously reported. ${ }^{10,11}$
While increased secretion of glutamic acid from HIV-1infected $\mathrm{T}$ cells has to our knowledge not previously been reported, there are consistent reports of glutaminasedependent glutamic acid secretion from HIV-1-infected macrophages and microglial cells and this is thought to contribute to the pathology of AIDS-related dementia. ${ }^{46-53}$

Our current work suggests that secretion of glutamic acid is a more general feature of HIV-1-infected cells, although the underlying mechanisms may be different for each cell-type. One recent study proposed that the enhanced glutamic acid production in macrophages is due to HIV-1 Vpr-mediated enhancement of flux through the glycolytic and citric acid cycle pathways with a concomitant increase in extracellular glutamic acid concentrations. ${ }^{54}$ However, it must be noted that the majority of that work was carried out with cells transduced with HIV-1 Vpr instead of HIV-1-infected cells. Datta et al. therefore attributed an important role to $\mathrm{Vpr}$ in modulating carbon metabolism in macrophages. ${ }^{54}$ We have not observed any effect of deleting Vpr from HIV-1 NL4.3 on glycolytic metabolism in infected $\mathrm{CD} 4^{+} \mathrm{T}$ cells (not shown: Kavanagh Williamson et al., article in preparation).

The conversion of glutamine to glutamic acid can be enzymatically performed in a variety of ways. The enzyme glutaminase, of which $\mathrm{T}$ cells express the KGA and GAC isoforms, ${ }^{55}$ catalyses this step by generating a free $\mathrm{NH}_{3}$ molecule (Fig. 5C). Alternatively, the enzyme PPAT generates glutamic acid from glutamine as the nitrogen is donated toward nucleotide biosynthesis and GFPT1 targets the nitrogen toward glucosamine biosynthesis (Fig. 5C). There are many more enzymes that act on glutamine, but antibodies are not commercially available for all of these. We, therefore, analyzed the expression of a defined set of enzymes that act on glutamine and demonstrated differential expression of KGA, GAC, and PPAT, but not GFPT1, in HIV-1-infected cells.

We note that, while we observed increased expression of KGA and decreased expression of GAC in HIV-1-infected $\mathrm{CD}^{+} \mathrm{T}$ cells, the opposite has been reported in infected macrophages. ${ }^{48,50}$ The reasons for this difference are as yet unclear.

In conclusion, our current study demonstrates that cellular glutamine metabolism is altered upon infection of human primary $\mathrm{CD}^{+} \mathrm{T}$ cells with HIV-1 and resulting in increased secretion of glutamic acid from the infected cells. Furthermore, we demonstrated that HIV-1 replication is responsive to the availability of glutamine, although we were unable to dissect this from the requirement of glutamine for cell survival. In conjunction with previous studies on HIV-1-infected macrophages, our work suggests that glutamic acid secretion is a more general feature of HIV-1-infected cells. With the current surge in interest in metabolism in human health and disease, glutamine metabolism merits further attention as regards its role in HIV-1 pathogenesis and as a potential target for future antiretroviral strategies.

\section{Acknowledgments}

This work was supported by the MRC through a Newton Fund Strategic Award (MR/M026213/1) to H.H. and A.T.P., and a New Investigator Research Grant (MR/J008125/1) to H.H.

\section{Author Disclosure Statement}

No competing financial interests exist. 


\section{References}

1. Pearce EL: Metabolism in T cell activation and differentiation. Curr Opin Immunol 2010;22:314-320.

2. Maciolek JA, Pasternak JA, Wilson HL: Metabolism of activated T lymphocytes. Curr Opin Immunol 2014;27:60-74

3. Chang $\mathrm{CH}$, Pearce EL: Emerging concepts of $\mathrm{T}$ cell metabolism as a target of immunotherapy. Nat Immunol 2016; 17:364-368.

4. Buck MD, Sowell RT, Kaech SM, Pearce EL: Metabolic instruction of immunity. Cell 2017;169:570-586.

5. Munger J, Bennett BD, Parikh A, et al.: Systems-level metabolic flux profiling identifies fatty acid synthesis as a target for antiviral therapy. Nat Biotechnol 2008;26:11791186.

6. Munger J, Bajad SU, Coller HA, Shenk T, Rabinowitz JD: Dynamics of the cellular metabolome during human cytomegalovirus infection. PLoS Pathog 2006;2:e132.

7. $\mathrm{Yu}$ Y, Clippinger AJ, Alwine JC: Viral effects on metabolism: Changes in glucose and glutamine utilization during human cytomegalovirus infection. Trends Microbiol 2011; 19:360-367.

8. Ritter JB, Wahl AS, Freund S, Genzel Y, Reichl U: Metabolic effects of influenza virus infection in cultured animal cells: Intra- and extracellular metabolite profiling. BMC Syst Biol 2010;4:61.

9. Hollenbaugh JA, Montero C, Schinazi RF, Munger J, Kim B: Metabolic profiling during HIV-1 and HIV-2 infection of primary human monocyte-derived macrophages. Virology 2016;491:106-114.

10. Hollenbaugh JA, Munger J, Kim B: Metabolite profiles of human immunodeficiency virus infected CD4+ T cells and macrophages using LC-MS/MS analysis. Virology 2011; 415:153-159.

11. Hegedus A, Kavanagh Williamson M, Huthoff H: HIV-1 pathogenicity and virion production are dependent on the metabolic phenotype of activated CD4+ T cells. Retrovirology 2014;11:98.

12. Vastag L, Koyuncu E, Grady SL, Shenk TE, Rabinowitz JD: Divergent effects of human cytomegalovirus and herpes simplex virus-1 on cellular metabolism. PLoS Pathog 2011;7:e1002124.

13. Goodwin CM, Xu S, Munger J: Stealing the keys to the kitchen: Viral manipulation of the host cell metabolic network. Trends Microbiol 2015;23:789-798.

14. El-Bacha T, Da Poian AT: Virus-induced changes in mitochondrial bioenergetics as potential targets for therapy. Int J Biochem Cell Biol 2013;45:41-46.

15. El-Bacha T, Menezes MM, Azevedo e Silva MC, SolaPenna M, Da Poian AT: Mayaro virus infection alters glucose metabolism in cultured cells through activation of the enzyme 6-phosphofructo 1-kinase. Mol Cell Biochem 2004;266:191-198.

16. El-Bacha T, Midlej V, Pereira da Silva AP, et al.: Mitochondrial and bioenergetic dysfunction in human hepatic cells infected with dengue 2 virus. Biochim Biophys Acta 2007; 1772:1158-1166.

17. Silva da Costa L, Pereira da Silva AP, Da Poian AT, ElBacha T: Mitochondrial bioenergetic alterations in mouse neuroblastoma cells infected with Sindbis virus: Implications to viral replication and neuronal death. PLoS One 2012;7:e33871.

18. Spencer CM, Schafer XL, Moorman NJ, Munger J: Human cytomegalovirus induces the activity and expression of acetyl-coenzyme A carboxylase, a fatty acid biosynthetic enzyme whose inhibition attenuates viral replication. J Virol 2011;85:5814-5824.

19. Levy PL, Duponchel S, Eischeid H, et al.: Hepatitis C virus infection triggers a tumor-like glutamine metabolism. Hepatology 2017;65:789-803.

20. Thai M, Thaker SK, Feng J, et al.: MYC-induced reprogramming of glutamine catabolism supports optimal virus replication. Nat Commun 2015;6:8873.

21. Fu X, Hu X, Li N, et al.: Glutamine and glutaminolysis are required for efficient replication of infectious spleen and kidney necrosis virus in Chinese perch brain cells. Oncotarget 2017;8:2400-2412.

22. Sanchez EL, Carroll PA, Thalhofer AB, Lagunoff M: Latent KSHV infected endothelial cells are glutamine addicted and require glutaminolysis for survival. PLoS Pathog 2015; 11:e1005052.

23. Fontaine KA, Camarda R, Lagunoff M: Vaccinia virus requires glutamine but not glucose for efficient replication. J Virol 2014;88:4366-4374.

24. Chambers JW, Maguire TG, Alwine JC: Glutamine metabolism is essential for human cytomegalovirus infection. J Virol 2010;84:1867-1873.

25. El-Bacha T, Struchiner CJ, Cordeiro MT, et al.: $1 \mathrm{H}$ nuclear magnetic resonance metabolomics of plasma unveils liver dysfunction in dengue patients. J Virol 2016;90:7429-7443.

26. Mills PB, Struys E, Jacobs C, et al:: Mutations in antiquitin in individuals with pyridoxine-dependent seizures. Nat Med 2006;12:307-309.

27. Blom HJ, van Rooij A, Hogeveen M: A simple highthroughput method for the determination of plasma methylmalonic acid by liquid chromatography-tandem mass spectrometry. Clin Chem Lab Med 2007;45:645-650.

28. Wishart DS, Tzur D, Knox C, et al.: HMDB: The Human Metabolome Database. Nucleic Acids Res 2007;35:D521D526.

29. McKnight TR, Yoshihara HA, Sitole LJ, Martin JN, Steffens F, Meyer D: A combined chemometric and quantitative NMR analysis of HIV/AIDS serum discloses metabolic alterations associated with disease status. Mol Biosyst 2014;10:2889-2897.

30. Ziegler TR, Judd SE, Ruff JH, McComsey GA, Eckard AR: Amino acid concentrations in HIV-infected youth compared to healthy controls and associations with CD4 counts and inflammation. AIDS Res Hum Retroviruses 2017;33:681-689.

31. Scalise M, Pochini L, Galluccio M, Indiveri C: Glutamine transport. From energy supply to sensing and beyond. Biochim Biophys Acta 2016;1857:1147-1157.

32. Bhutia YD, Ganapathy V: Glutamine transporters in mammalian cells and their functions in physiology and cancer. Biochim Biophys Acta 2016;1863:2531-2539.

33. Ren W, Liu G, Yin J, et al.: Amino-acid transporters in Tcell activation and differentiation. Cell Death Dis 2017;8: e2655.

34. Horig H, Spagnoli GC, Filgueira L, et al.: Exogenous glutamine requirement is confined to late events of $\mathrm{T}$ cell activation. J Cell Biochem 1993;53:343-351.

35. Nicklin $\mathrm{P}$, Bergman $\mathrm{P}$, Zhang $\mathrm{B}$, et al:: Bidirectional transport of amino acids regulates mTOR and autophagy. Cell 2009;136:521-534.

36. Kurihara T, Arimochi H, Bhuyan ZA, et al.: CD98 heavy chain is a potent positive regulator of CD4+ $\mathrm{T}$ cell proliferation and interferon-gamma production in vivo. PLoS One 2015;10:e0139692. 
37. Komada H, Imai A, Hattori E, et al: Possible activation of murine T lymphocyte through CD98 is independent of interleukin 2 /interleukin 2 receptor system. Biomed Res 2006;27:61-67.

38. Cantor J, Slepak M, Ege N, Chang JT, Ginsberg MH: Loss of $\mathrm{T}$ cell $\mathrm{CD} 98 \mathrm{H}$ chain specifically ablates $\mathrm{T}$ cell clonal expansion and protects from autoimmunity. J Immunol 2011;187:851-860.

39. Carr EL, Kelman A, Wu GS, et al.: Glutamine uptake and metabolism are coordinately regulated by ERK/MAPK during T lymphocyte activation. J Immunol 2010;185:1037-1044.

40. Wang R, Dillon CP, Shi LZ, et al.: The transcription factor Myc controls metabolic reprogramming upon $\mathrm{T}$ lymphocyte activation. Immunity 2011;35:871-882.

41. Taylor HE, Simmons GE Jr., Mathews TP, et al.: Phospholipase D1 couples CD4+ T cell activation to c-Mycdependent deoxyribonucleotide pool expansion and HIV-1 replication. PLoS Pathog 2015;11:e1004864.

42. Nakaya M, Xiao $\mathrm{Y}$, Zhou X, et al.: Inflammatory $\mathrm{T}$ cell responses rely on amino acid transporter ASCT2 facilitation of glutamine uptake and mTORC1 kinase activation. Immunity 2014;40:692-705.

43. Varoqui H, Zhu H, Yao D, Ming H, Erickson JD: Cloning and functional identification of a neuronal glutamine transporter. J Biol Chem 2000;275:4049-4054.

44. Matheson NJ, Sumner J, Wals K, et al.: Cell surface proteomic map of HIV infection reveals antagonism of amino acid metabolism by Vpu and Nef. Cell Host Microbe 2015; 18:409-423.

45. Pochini L, Scalise M, Galluccio M, Indiveri C: Membrane transporters for the special amino acid glutamine: Structure/function relationships and relevance to human health. Front Chem 2014;2:61.

46. Thomas AG, O’Driscoll CM, Bressler J, Kaufmann W, Rojas CJ, Slusher BS: Small molecule glutaminase inhibitors block glutamate release from stimulated microglia. Biochem Biophys Res Commun 2014;443:32-36.

47. Jiang ZG, Piggee C, Heyes MP, et al.: Glutamate is a mediator of neurotoxicity in secretions of activated HIV-1infected macrophages. J Neuroimmunol 2001;117:97-107.
48. Huang Y, Zhao L, Jia B, et al:: Glutaminase dysregulation in HIV-1-infected human microglia mediates neurotoxicity: Relevant to HIV-1-associated neurocognitive disorders. J Neurosci 2011;31:15195-15204.

49. Porcheray F, Leone C, Samah B, et al.: Glutamate metabolism in HIV-infected macrophages: Implications for the CNS. Am J Physiol Cell Physiol 2006;291:C618-C626.

50. Erdmann $\mathrm{N}$, Tian $\mathrm{C}$, Huang $\mathrm{Y}$, et al.: In vitro glutaminase regulation and mechanisms of glutamate generation in HIV1-infected macrophage. J Neurochem 2009;109:551-561.

51. Erdmann N, Zhao J, Lopez AL, et al.: Glutamate production by HIV-1 infected human macrophage is blocked by the inhibition of glutaminase. J Neurochem 2007;102:539-549.

52. Tian C, Erdmann N, Zhao J, Cao Z, Peng H, Zheng J: HIVinfected macrophages mediate neuronal apoptosis through mitochondrial glutaminase. J Neurochem 2008;105:994-1005.

53. Zhao J, Lopez AL, Erichsen D, et al.: Mitochondrial glutaminase enhances extracellular glutamate production in HIV-1-infected macrophages: Linkage to HIV-1 associated dementia. J Neurochem 2004;88:169-180.

54. Datta PK, Deshmane S, Khalili K, et al:: Glutamate metabolism in HIV-1 infected macrophages: Role of HIV-1 Vpr. Cell Cycle 2016;15:2288-2298.

55. Sener Z, Cederkvist FH, Volchenkov R, Holen HL, Skalhegg BS: T helper cell activation and expansion is sensitive to glutaminase inhibition under both hypoxic and normoxic conditions. PLoS One 2016;11:e0160291.

Address correspondence to:

Dr. Hendrik Huthoff

Jena School for Microbial Communication

Friedrich Schiller University Jena

Neugasse 23

07743 Jena

Germany

E-mail: hendrik.huthoff@uni-jena.de 